\title{
LETTER
}

\section{Development of anti-citrullinated protein antibody and rheumatoid factor isotypes prior to the onset of rheumatoid arthritis}

\author{
Wouter H Bos ${ }^{1}$, Lotte A van de Stadt ${ }^{2}$, Azita Sohrabian ${ }^{3}$, Johan Rönnelid ${ }^{3}$ and Dirkjan van Schaardenburg ${ }^{1,2^{*}}$
}

\section{Introduction}

We and others have previously shown that the development of rheumatoid arthritis (RA) is preceded by IgG anti-citrullinated protein antibody (ACPA) and rheumatoid factor (RF) [1,2]. Furthermore, it was shown that other isotypes of ACPA (IgA and, to a lesser extent, the IgM isotype) also predate the onset of RA [3]. Moreover, smoking has been linked to the development of IgA ACPA in the preclinical phase [3].

We have extended these observations by using a previously described RA cohort in which serial preclinical serum samples were available [2]. Three sequential serum samples from 30 IgG ACPA-positive RA patients who had donated blood before disease onset were selected and were tested for IgM, IgA, and IgG isotypes of ACPA (using the anti-cyclic citrullinated peptide 2 test) and RF, as described previously, by using the ImmunoCap system (Phadia, Uppsala, Sweden) [3]. Smoking status (current or past smoker versus never smoked) was obtained retrospectively by chart review for 24 patients.

\section{Results}

For IgA ACPA, $57 \%$ of the initial samples (median of 5.7 years pre-diagnosis) were positive, increasing to $77 \%$ in the last available sample, at a median of 0.6 years prediagnosis. All but one patient was positive for IgG ACPA at all time points. For IgM ACPA, 20\% of patients were initially positive, increasing to $43 \%$ in the last prediagnosis sample (Table 1). The median ACPA levels rose significantly (Figure 1 ).

For RF, $67 \%, 13 \%$, and $47 \%$ of the initial samples were positive for IgA, IgG, and IgM, respectively. These percentages increased in time to $87 \%, 37 \%$, and $83 \%$ of

\footnotetext{
* Correspondence: d.v.schaardenburg@reade.nl

${ }^{1}$ Department of Rheumatology, VU University Medical Center, De Boelelaan

117, 1081 HV Amsterdam, The Netherlands

${ }^{2} J a n$ van Breemen Research Institute | Reade, dr. Jan van Breemenstraat 1 ,

1056 AB Amsterdam, The Netherlands

Full list of author information is available at the end of the article
}

patients, respectively (Table 1 ). The median RF levels rose significantly (Figure 1).

Smoking tended to be associated with higher IgA ACPA and IgA RF levels, especially in the last prediagnosis sample, with median levels of 61 versus $13 \mathrm{AU} / \mathrm{mL}$ and 87 versus $11 \mathrm{IU} / \mathrm{mL}$ in smokers versus non-smokers, respectively $(P=0.2$ and 0.06 , MannWhitney $U$ test).

\section{Conclusions}

In the preclinical phase of RA, IgG ACPA comes first, followed by IgA, and then by IgM. For RF, the IgG subtype seems to appear after IgA and IgM. As postulated previously [3], the IgG-dominated anti-CCP pattern might reflect a mature $\mathrm{T}$ cell-dependent immune reaction, whereas the IgM-dominated RF response might represent a non-isotype switched $\mathrm{T}$ cell-independent immune response. All investigated autoantibodies rise over time before RA diagnosis. Finally, smoking seems to influence both IgA APCA and IgA RF levels and this is in line with the hypothesis that smoking induces or augments a mucosa-related immune response in lungs.

Table 1 Number (percentage) of autoantibody-positive patients pre-diagnosis

\begin{tabular}{lccc}
\hline $\begin{array}{l}\text { Autoantibody- } \\
\text { positive } \\
\text { patients, } \\
\text { number } \\
\text { (percentage) }\end{array}$ & \multicolumn{3}{c}{ Years pre-diagnosis, median (IQR) } \\
\cline { 2 - 4 } $\mathbf{5 . 7}(\mathbf{4 . 0}-\mathbf{6 . 3})$ & $\mathbf{2 . 8}(\mathbf{1 . 9}-\mathbf{3 . 6})$ & $\mathbf{0 . 6}(\mathbf{0 . 4 - 1 . 1 )}$ \\
\hline IgA ACPA & $17(57)$ & $18(60)$ & $23(77)$ \\
IgG ACPA & $29(97)$ & $29(97)$ & $30(100)$ \\
IgM ACPA & $6(20)$ & $11(37)$ & $13(43)$ \\
IgA RF & $20(67)$ & $23(77)$ & $26(87)$ \\
IgG RF & $4(13)$ & $5(17)$ & $11(37)$ \\
IgM RF & $14(47)$ & $21(70)$ & $25(83)$ \\
\hline ACPA
\end{tabular}

ACPA, anti-citrullinated protein antibody; IQR, interquartile range; $\mathrm{RF}$, rheumatoid factor. 


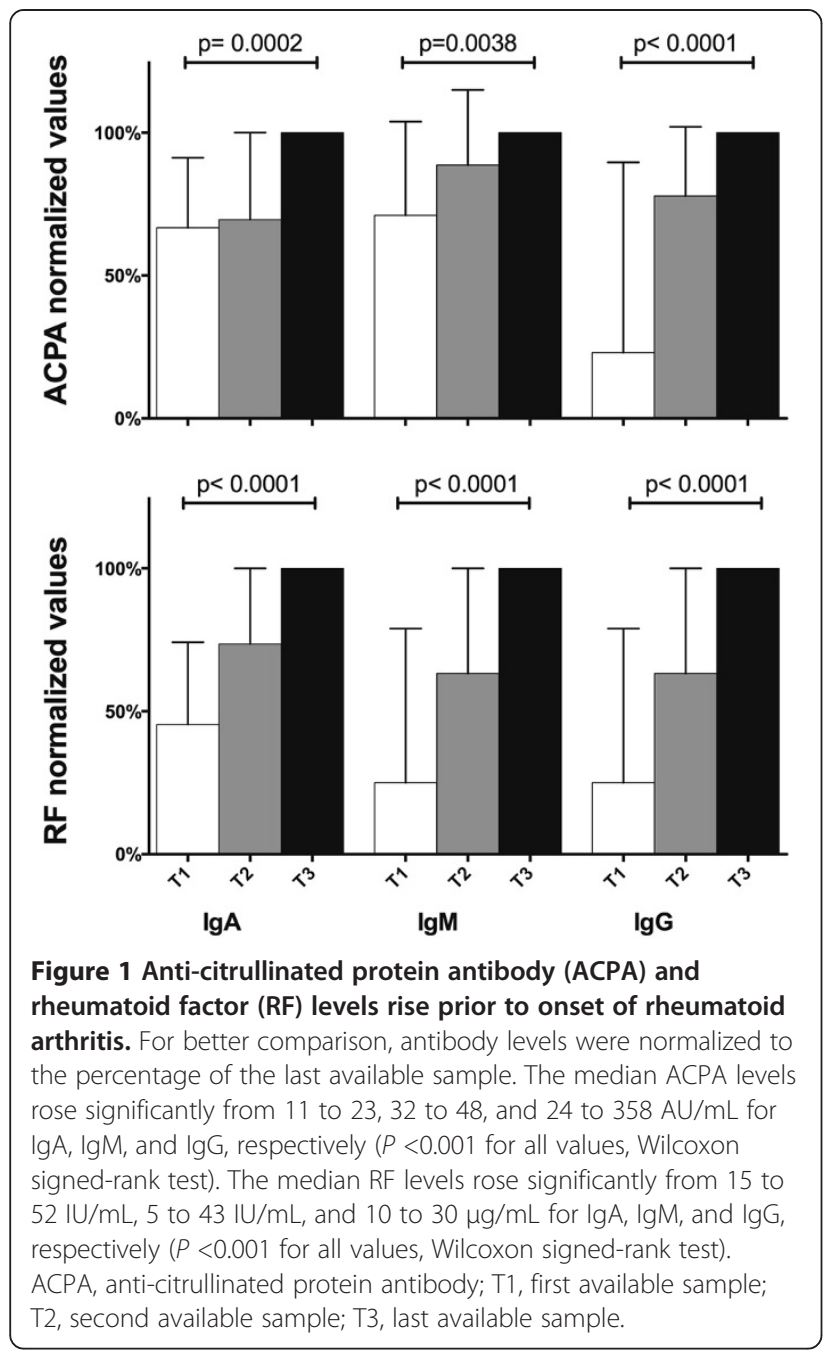

\section{Abbreviations}

ACPA: Anti-citrullinated protein antibody; anti-CCP: Anti-cyclic citrullinated peptide; RF: Rheumatoid factor.

\section{Competing interests}

The authors declare that they have no competing interests.

\section{Authors' contributions}

AS performed the RF and cyclic citrullinated peptide assays. WHB performed the analysis of the data. All authors were involved in the conception, design, and interpretation of data and in drafting the article and revising it critically for important intellectual content and read and approved the final manuscript.

\section{Acknowledgments}

The study was approved by the local institutional review board (METC Slotervaart en Reade), and written informed consent was obtained from all participants.

\section{Author details}

'Department of Rheumatology, VU University Medical Center, De Boelelaan 117, 1081 HV Amsterdam, The Netherlands. ${ }^{2}$ Jan van Breemen Research Institute | Reade, dr. Jan van Breemenstraat 1, 1056 AB Amsterdam, The Netherlands. ${ }^{3}$ Department of Immunology, Genetics and Pathology, Uppsala University, Redbecklaboratoriet, 751 85, Uppsala, Sweden.

\section{References}

1. Rantapää-Dahlqvist S, de Jong BA, Berglin E, Hallmans G, Wadell G, Stenlund H, Sundin U, van Venrooij WJ: Antibodies against cyclic citrullinated peptide and IgA rheumatoid factor predict the development of rheumatoid arthritis. Arthritis Rheum 2003, 48:2741-2749.

2. Nielen MM, van Schaardenburg D, Reesink HW, van de Stadt RJ, van der Horst-Bruinsma IE, de Koning MH, Habibuw MR, Vandenbroucke JP, Dijkmans BA: Specific autoantibodies precede the symptoms of rheumatoid arthritis: a study of serial measurements in blood donors. Arthritis Rheum 2004, 50:380-386.

3. Kokkonen H, Mullazehi M, Berglin E, Hallmans G, Wadell G, Rönnelid J, Rantapää-Dahlqvist S: Antibodies of IgG, IgA and IgM isotypes against cyclic citrullinated peptide precede the development of rheumatoid arthritis. Arthritis Res Ther 2011, 13:R13.

\section{$10.1186 /$ ar4511}

Cite this article as: Bos et al:: Development of anti-citrullinated protein antibody and rheumatoid factor isotypes prior to the onset of rheumatoid arthritis. Arthritis Research \& Therapy 2014, 16:405 